Przegląd Prawa Konstytucyjnego

----ISSN 2082-1212-----

DOI 10.15804/ppk.2018.03.12

-----Nr $3(43) / 2018-----$

\title{
Wspomnienie o Panu Profesorze Ryszardzie M. Małajnym
}

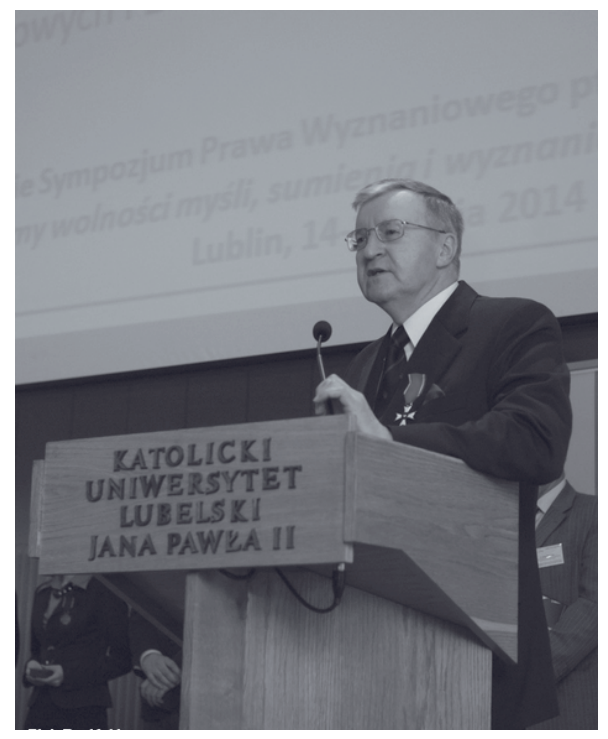

Ryszard Mariusz Małajny urodził się 15 grudnia 1953 r. w Krośnie Odrzańskim. Do Wrocławia przeprowadził się w 1965 r., gdzie, jak sam o sobie żartował „skończył wszystkie szkoły z wyjątkiem specjalnej”. Naukowcem chciał zostać od zawsze, by nie odwlekać kariery studia ukończył w ciągu 3 lat, a od uzyskania stopnia doktora w 1978 r. do profesury zwyczajnej w $2000 \mathrm{r}$. minęły jedynie 22 lata. Zwykł mawiać, że „naukowiec jest tyle wart, ile po sobie pozostawi”, a „w nauce jest jak w wojsku - wielu szeregowców, ale niewielu generałów". Publikował do samego końca, a niebawem ukaże się w Wydawnictwie Sejmowym jego ostatnia książka Europejski parlamentaryzm (około 1000 stron), która, wedle zamysłu Autora, stanowić będzie kompendium wiedzy w tym zakresie. 
Cenił sobie dobrą organizację i każdy dzień starannie planował, to dzięki temu sprawnie godził pracę zawodową z pozostałymi obowiązkami. Nie samą nauką jednak człowiek żyje, prywatnie prof. R.M. Małajnego można było często zobaczyć w ogrodzie ze szpadlem i taczkami, czy koszącego trawnik. Prace w ogrodzie bardziej traktował jak formę relaksu, a przy okazji dbał o kondycję. Uważał, że „nic tak nie męczy, jak bezczynność”, a każdy dzień starał się spędzić z lekturą lub pisząc, nie wyłączając nawet jednego dnia w roku.

Pasjonowała go historia, a zwłaszcza historia wojskowości. Uważał, że w mundurze mężczyzna wygląda dziarsko, z przyjemnością zakładał różne elementy garderoby wojskowej tworząc niepowtarzalną „mieszankę firmową” i nie mogło być inaczej skoro był zwolennikiem porządku, dyscypliny i efektywnego działania. Postać charakterystyczna zarówno na uczelni, jak i w miejscu zamieszkania. Zielona wojskowa kurtka, czapka, wojskowe buty, charakterystyczny znak rozpoznawczy - idzie prof. Małajny.

Lubiany przez studentów dydaktyk, żartobliwy, ale też i wymagający; ceniony w środowisku konstytucjonalistów, historyków doktryn i specjalistów prawa wyznaniowego autorytet. Realizował się również w lżejszej formule, czemu dał wyraz w przykazaniach egzaminacyjnych znanych również po drugiej stronie oceanu.

Wesoły, miał duży dystans do siebie, stąd żartował zarówno na wykładach, jak i w przy okazji prywatnych spotkań, a często na zakończenie rozmowy można było od niego usłyszeć jakiś dowcip, przez co kontakt z nim przyjemnie utrwalał się w pamięci. Wrażliwy na krzywdę drugiego człowieka, nie zwlekał z udzieleniem pomocy. Dla najbliższych kochający mąż i ojciec, troskliwy i zapobiegawczy, gotów do poświęceń, wymagający - choć najwięcej od siebie.

Spisywał co cenniejsze aforyzmy i często przytaczał właśnie ten: „Kto nie zna wartości czasu, ten nie zna wartości życia”.

opracowanie: Doktor Iwona Małajny 
Pana Profesora Ryszarda M. Małajnego nie ma już śród nas, jednak nadal pozostaje obecny w pamięci Swych przyjaciół, koleżanek, kolegów oraz uczniów. Wyrazem tego są wspomnienia o Profesorze przygotowane przez przedstawicieli nauki prawa konstytucyjnego, osoby, które pozostawały z Nim w bliskich relacjach. Oto niektóre z nich:

\section{Wspomnienie Profesora Andrzeja Sylwestrzaka}

Moje wspomnienie o Profesorze Ryszardzie Małajnym dotyczy trzech spotkań jakie miałem z nim w trakcie zjazdów doktryn politycznych. Pierwszy zorganizowany przez Katedrę Historii Państwa i Prawa Polskiego WPiA UG w 2001 r. w Juracie, drugie w 2002 r. zorganizowane przez Katedrę Historii Doktryn WPiA UMCS w Krasnobrodzie oraz trzecie zorganizowane w Krakowie przez WPiA UJ. Otóż poznałem Prof. R. Małajnego na pierwszym zjeździe historii doktryn zorganizowanym przez ośrodek wrocławski w Świeradowie-Zdroju. Wówczas, z racji szczególnych upodobań Prof. R. Małajnego do oryginalnych strojów w stylu raczej militarnym myślałem, że na zjazd przyjechał w panterce jakiś myśliwy. Niebawem okazało się, że jest to z Katowic Prof. R. Małajny i od tej pory datuje się nasza przyjaźń. W ramach tego, korzystając z zaproszenia, odwiedziłem Prof. Małajnego w jego nowo wybudowanym, chociaż jeszcze nie ukończonym, domu jednorodzinnym w miejscowości Kobiór między Tychami a Bielskiem-Białą. Wówczas zaskoczył mnie rozmach samej budowli m. zd. przekraczającej czterysta metrów kwadratowch. Rysio uzasadniał to sporą rodziną jaką posiada składającą się z Szanownej Małżonki i trzech naówczas jeszcze w wieku szkolnym synów. Na pierwszy rzut oka fascynowało mnie zamiłowanie Rysia do dziwnych strojów wyjściowych szytych na wzór mundurów wojskowych bliżej nieokreślonej armii. Nawet w dowód naszej przyjaźni podarował mi swoje zdjęcia ślubne, gdzie zawierając w kościele ewangelickim związek małżeński, również wystąpił w umundurowaniu militarnym. Pytałem Jego asystentów skąd ten zamysł do w końcu trochę egzotycznych ubrań noszonych również na zajęciach dydaktycznych, które podobno sam projektował i po części wykonywał, ale nigdy nie otrzymałem pełniejszej odpowiedzi. Także na zjeździe doktryn w Szczyrku, organizowanym Przezeń z ramienia WPiA UŚl, każdego dnia prezentował się w innym mundurze. W końcu wszyscy przy- 
zwyczaili się do tej ekstrawagancji Rysia i nie budził już takiej sensacji, chociaż przy każdym kolejnym spotkaniu zastanawiałem się w jakiej konwencji militarnej wystąpi. Ostatni raz widziałem Go na zjeździe Krakowie, gdzie ubral się w białą z grubego sukna marynarkę i czarne spodnie, a na rękawach marynarki miał jakieś egzotyczne naszywki w rodzaju New Zeeland Army.

Niestety na zjeździe w Juracie zorganizowanym przez ośrodek gdański Rysio przyjechał w tradycyjnym garniturze i tak pozostał do końca obrad. Właśnie wtedy rozpocząłem z Nim niedokończoną dyskusję na temat nowoczesnej klasyfikacji podziału władz. Działo się to na tle opublikowanej Przezeń w Wydawnictwie Sejmowym, Warszawa 2001, monografii Trzy teorie podzielonej wła$d z y$, gdzie zakładając tradycyjny trójpodział analizował jego wersje szczególnie w brytyjskim systemie parlamentarnym, dowodząc różnych niekonsekwencji w praktycznym pojmowaniu granic samej władzy ustawodawczej, wykonawczej i sądowniczej. W Juracie starałem się wysunąć koncepcję, iż w państwie współczesnym jednak zasadniczą klasyfikacją jest podział na władzę rządzącą, władzę opozycyjną i władzę neutrlną. Tę sprawę podjęliśmy na zjeździe w Krakowie, ale niestety Rysiu pozostawał opozycjonistą trzymając się rygorystycznie klasyfikacji konstytucyjnych. W końcu przystał na możliwość wyróżnienia w miejsce władzy sądowniczej tzw. władzy neutralnej obejmującej całość sądownictwa, rzeczników praw obywatelskich i kontrolę państwową, aczkolwiek nie dał temu wyrazu w kolejnych swoich publikacjach. W sumie dyskusje z Rysiem wokół problemów podziału władz i szans osiągnięcia tą drogą równowagi w państwie (aequilibritatis), pozostawiły w mojej koncepcji wiele inspiracji, będąc wzorcowym w świecie naukowym modelem przyjaźni-dyskusji.

O ile sobie przypominam, to Rysiu najbardziej - w sensie doktrynalnym przychylał się do klasyfikacji władz według Alexisa de Tocquevilla, szczególnie rozbudowując tzw. władzę reprezentacyjną czyli neutralną. Przenosił to na koncepcję urzędu Pezydenta RP wg Konstytucji z 1997 r. a szczególnie zastanawiał się nad nową przebudową systemu organów państwowych w dzisiejszej Polsce pod kątem wyeksponowania systemu kanclerskiego najbardziej sprzyjającego właśnie neutralnej, w sensie politycznym, pozycji głowy państwa. Chodziło Mu głównie o pogłębienie gwarancji „równowagi” władz, gdzie instytucją koordynującą współdziałanie władz byłaby właśnie instytucja prezydenta. Trudno odmówić trafności dla tych rozwiązań w zasadniczym sensie pozostających pod wpływem konstytucjonalizmu RFN. 
Wiadomość o nagłej śmierci Prof. R. Małajnego bardzo przeżyłem, w jakimś senmsaie nie mogłem się z tym pogodzić. Chodziło o to że Człowiek dopiero mający zamiar składać podania o emeryturę po ukończeniu $65 \mathrm{roku}$ życia, już odszedł. Pozostanie jednak w mojej pamięci jako niezwykle twórczy naukowiec, wielki oryginał i ogólnie ceniony przez studentów dydaktyk.

\section{Wspomnienie Profesora Jerzego Jaskierni}

Nasze drogi naukowe przecinały się wielokrotnie, bo znacząca część dorobku naukowego prof. R.M. Małajnego dotyczy ustroju oraz doktryn polityczno-prawnych Stanów Zjednoczonych Ameryki. Na szczególną uwagę zasługuje tu wielotomowe dzieło dotyczące Kongresu Stanów Zjednoczonych. Duży rozgłos przyniosły też Autorowi prace dotyczące zasady podziału władzy, zwłaszcza Doktryna podziału władzy „Ojców Konstytucji” USA (Katowice 1985). Wszystkie Jego opracowania cechowała erudycja, doskonałe rozeznanie w literaturze przedmiotu i umiejętność formułowania oryginalnych myśli. Mogłem się o tym przekonać recenzując dla Wydawnictwa Sejmowego w 2012 r., kto wie czy nie najważniejsze Jego dzieło: Amerykański prezydencjalizm.

Wybierał tematy trudne, nośne naukowo, istotne dla teorii prawa konstytucyjnego. Jego dorobek, zapoczątkowany w okresie PRL-u, wpisuje się w ten nurt podejmowanych wówczas badań porównawczych, które spowodowały, że u progu III RP polska nauka prawa konstytucyjnego dysponowała wartościowym know how w kwestii kreowania i funkcjonowania demokratycznych instytucji ustrojowych.

Moją uwagę zwróciły też opracowania R.M. Małajnego dotyczące stosunków państwo - Kościół w Konstytucji RP. Nie wahał się formułować odważne sądy w materii, którą inni autorzy podejmowali z najwyższą ostrożnością. Dopiero później dowiedziałem się, że R.M. Małajny pełnił wysoką funkcję w jednym z kościołów protestanckich.

Pod koniec ubiegłego roku R.M. Małajany zwrócił się do mnie o przesłanie dedykowanych mi ksiąg jubileuszowych, w których umieścił swe opracowania. Czyżby porządkował swój dorobek naukowy w świadomości, że kres Jego drogi życiowej dobiega końca? 


\section{Wspomnienie Profesora Stanisława Bożyka}

Profesor Ryszard M. Małajny odszedł tak nagle i niespodziewanie, że wręcz trudno w to uwierzyć. Tym bardziej, że Jego życie dobiegło kresu w pełni sił twórczych, kiedy mógł stworzyć jeszcze kolejne dzieła naukowe, podejmujące - jak zawsze - trudne i niezbadane do końca problemy prawnoustrojowe. Nie pojawi się już wśród nas na różnych konferencjach konstytucjonalistów w tym swoim mundurze, jakże charakterystycznym, ale przy tym bardzo dobrze skrojonym. Nie usłyszymy też Jego bardzo interesujących wystąpień oraz niezwykle barwnych opowieści. Poza bogatym dorobkiem naukowym, pozostawił po sobie również znamienite „Przykazania egzaminacyjne".

Ryszarda spotkałem po raz pierwszy i poznałem bliżej 38 lat temu przy okazji Zjazdu Katedr Prawa Konstytucyjnego w Wigrach w czerwcu 1980 r. Jednak nie nad Jeziorem Wigry lecz nad Jeziorem Necko. Wysiadłem wówczas w Augustowie z autokaru, którym uczestnicy Zjazdu (organizowanego przez UW) wracali przez Łomżę do Warszawy. Za mną opuścił autokar także młody człowiek, którego widziałem podczas obrad sesji i na statku, gdy odbywał się rejs po jeziorze. Okazało się, że był to Ryszard, już wtedy po obronie doktoratu, który postanowił odwiedzić swoją rodzinę mieszkającą w okolicy Dąbrowy Białostockiej. Do odjazdu pociągu do Białegostoku było wówczas jeszcze prawie 3 godziny, poszliśmy więc na obiad do restauracji „Warszawa”, a następnie siedzieliśmy i rozmawialiśmy tuż nad brzegiem Jeziora Necko. Pamiętam, że Ryszard wysiadł z pociągu na stacji Różanystok pod Dąbrową. W takich właśnie okolicznościach poznałem późniejszego Profesora R.M. Małajnego.

Z Ryszardem stosunkowo często korespondowałem drogą mailową. Po raz ostatni na kilka miesięcy przed Jego nagłą śmiercią. Pytał mnie wówczas o możliwość opublikowania w Księdze Jubileuszowej Prof. A. Jamroza artykułów dwóch Jego doktorantów. Gdy napisałem $\mathrm{Mu}$, że nie widzę przeszkód, był wielce uradowany i zapowiedział, że przyjedzie oczywiście na uroczystości jubileuszowe (sam zresztą napisał artykuł do tej Księgi). Niestety, nie będę miał już możliwości powitać Ryszarda w lipcu w Białymstoku. 


\section{Wspomnienie Profesora Mariusza Jagielskiego}

Profesor Ryszard Mariusz Małajny - wykładowca, promotor, człowiek nauki. Miałem możliwość poznać Go w każdej z tych ról. Każdą wypełniał z ogromnym zaangażowaniem, oddaniem, pasją, nierzadko poświęceniem.

Najpierw poznałem go jako Wykładowcę - jako student uczestniczyłem w prowadzonych przez Niego ćwiczeniach z prawa konstytucyjnego, konwersatorium $z$ nauki o polityce oraz wykładach $z$ historii doktryn politycznych i prawnych. Zawsze gromadził pełną salę, bo nawet jeśli jakiś student nie był zbytnio zainteresowany przedmiotem, to na zajęcia Profesora warto było przyjść: były prowadzone „lekko”, ze swadą i humorem, a jednocześnie były wypełnione porządną merytoryczną treścią. Czas płynął na nich szybko, ale w głowach pozostawało dużo.

Potem został moim Promotorem - wpierw pracy magisterskiej, potem doktorskiej. Także w tej roli Profesor sprawdzał się znakomicie. Z jednej strony był surowym recenzentem przynoszonych mu treści. Czytał je dokładnie, wyłapywał wszystkie błędy, nie tylko merytoryczne, ale także językowe, bardzo dbając o to, by prace były poprawne pod każdym względem. Z drugiej strony był bardzo pomocnym opiekunem naukowym. Często i chętnie udostępniał swoim podopiecznym bogate zasoby źródeł i materiałów naukowych, normalnie trudnych do zdobycia, a zgromadzonych podczas Jego zagranicznych wyjazdów (do dzisiaj przechowuję kserokopie artykułów, które Profesor przywiózł z Wielkiej Brytanii i USA, a które przekazał mi na potrzeby pisania doktoratu - na niektórych znajdują się Jego odręczne notatki). Profesor był też znany z tego, że bardzo szybko, choć zawsze rzetelnie, czytał i sprawdzał oddawane Mu prace. Generalnie Profesor zawsze pracował tak, by nie marnować ani chwili... jakby czuł, że tego czasu nie będzie miał zbyt wiele.

Był wreszcie Profesor Naukowcem, prawdziwym, wybitnym Uczonym. Nigdy nie bał się podejmować tematów trudnych, w danym momencie niepopularnych. Liczyła się tylko ich wartość naukowa. Warto przypomnieć, że przybliżał polskim czytelnikom amerykańskie koncepcje ustrojowe (Doktryna podziału władzy „Ojców Konstytucji” USA, 1985) w latach 80., tuż po zakończeniu stanu wojennego, tematykę relacji państwo - związki wyznaniowe („Mur separacji” - państwo a kościół w Stanach Zjednoczo- 
nych Ameryki, 1992) podjął na początku lat 90., w czasie gorących dyskusji nad konkordatem. Czy może dziwić, że ostatnimi czasy prowadził badania nad konstytucjonalizmem i parlamentaryzmem - kwintesencją demokracji. Dzieła naukowe Profesora stanowiły rezultat szerokich i szczegółowych badań, przy tym nigdy nie ograniczały się do analizy, zawsze zawierały syntezy. Odznaczały się przy tym niepowtarzalnym stylem, swoistą lekkością, która powoduje, że ich lektura to nie tylko uczta intelektualna, ale też literacka. Jest banałem powiedzenie, że ktoś odcisnął swe piętno na dziedzinach, którymi się zajmował, ale w przypadku Profesora tak właśnie było. Tego nikt Mu nie odbierze.

Był Człowiekiem skromnym, a zarazem wielką Indywidualnością.

\section{Wspomnienie Profesora Radosława Grabowskiego}

Profesor Ryszard Małajny był niewątpliwie, jedną z najoryginalniejszych postaci naszego środowiska. Jego sposób bycia, zamiłowanie do nietypowych ubiorów, szczerość w wyrażaniu poglądów faktycznie czyniły go wyjątkowym. Wiele osób postrzegało Go jako dziwaka, ale zapewne nigdy nie poznali go bliżej, stąd też nie mieli okazji przekonać się jaki był naprawdę.

Utartymi ścieżkami nie chadzał, to pewne, ale na tym właśnie polegała Jego specyfika. W nauce był badaczem śmiało przełamującym schematy, ogrom posiadanej wiedzy nie przytłaczał Go, ale napędzał. Był przy tym solidny i uczciwie stawiał sprawy, nawet jeśli wiedział, że nie przysporzy $\mathrm{Mu}$ to sympatii. Często krytyczny, jednak nie popadał w krytykanctwo, był doskonałym towarzyszem długich naukowych dyskusji i zwykłych rozmów przy śniadaniu, inteligentnym i dowcipnym.

Cechowało Go niezwykłe poczucie humoru, kto inny zadałby sobie trud napisania dwu recenzji: tej oficjalnej - formalnej i poprawnej, a także tej nieoficjalnej - dowcipnej i nieco prześmiewczej, stworzonej dla żartu, którą zrozumieć mogły tylko osoby „nadające na tych samych falach”.

Jestem pewien, że nie zostanie zapomniany - legendy prawdziwych profesorów żyją długo po ich śmierci. A Ryszard taki właśnie był, prawdziwy. 


\section{Wspomnienie Profesor Agnieszki Bień-Kacały}

Pana Profesora Ryszarda Małajnego pamiętam ze względu na jego rzadko spotykane zamiłowanie do militarnych strojów, mundurów i rozmaitych części garderoby. Nie powinno zatem dziwić, że pas wojskowy mojego Taty stał się pretekstem do miłej rozmowy podczas naszego pierwszego spotkania blisko 20 lat temu. Od tego momentu przy każdej okazji wymienialiśmy serdeczności i podziwialiśmy wzajemnie militarne elementy własnych strojów i wojskowe gadżety. Oczywiście uznanie dla Profesora Małajnego nie ogranicza się do hobby, ale związane jest przede wszystkim z pracą naukową. Profesor miał niezwykły, otwarty umysł i pasję, z którą omawiał doktrynalne, teoretyczne i niekiedy filozoficzne wątki prawa konstytucyjnego. Jego miłe wspomnienie na zawsze pozostanie w mojej pamięci!

\section{Wspomnienie Profesor Sabiny Grabowskiej}

Zaczynając pisać wspomnienie o profesorze Ryszardzie Małajnym, przeglądnęłam skrzynkę mail-ową. I rzucił mi się na oczy, choć pewnie od Profesora za takie sformułowanie dostałabym po uszach, mail z datą $17 \mathrm{kwietni}$ 2012 r. - Wspomnienie o prof. W. Sokolewiczu. Pisze: „Droga Sabinko: Najmocniej przepraszam, ale zapomniałem na śmierć. Ale rzecz już odpokutowałem - vide załącznik. Serdeczności, R.” No właśnie, „na śmierć”. Minęło raptem 6 lat i teraz ja siedzę i mam napisać coś o Ryśku...

Co tu napisać? Przecież to jeszcze nie Jego czas na odejście. Że był wielkim naukowcem - wiadomo. Że był indywidualistą - też wiadomo. Przeczytałam tekst Jego Żony - Iwony. I podpisuję się pod nim obiema rękami. Rysiek miał wielka wiedzę, był oryginałem, ale kto z nas nim nie jest. Ale umiał też docenić innych i zachęcić do pracy. Miałam tego dowód w postaci recenzji wydawniczej Formy odpowiedzialności konstytucyjnej w państwach europejskich, która to książka powstała pod moja i Radka redakcją, a wydało ją Wydawnictwo Adam Marszałek w 2010 r.

Profesor Ryszard Małajny był jednym z recenzentów w moim postępowaniu o nadanie stopnia doktora habilitowanego. Powiem szczerze, że był tym 
Recenzentem, którego recenzji bałam się najbardziej. Z racji zainteresowań naukowych istniało duże prawdopodobieństwo, że Centralna Komisja Jego, właśnie, wyznaczy na Recenzenta mojego dorobku. Dlatego też, pisząc książkę starałam się zadbać nie tylko o stronę merytoryczną monografii, ale sprawdzałam też wielokrotnie, czy nie pozostał gdzieś zwrot „jeśli chodzi o...” czy też „... pełni rolę”, bo wiedziałam, że zaraz dowiedziałabym się, że: „chodzi się na spacer”, a „rolę gra się w teatrze”. Początkiem lipca sekretarz mojej komisji habilitacyjnej poinformował, że prof. R. Małajny przesłał już recenzję. Czytałam ją na bezdechu na środku ogrodu. Jak później opowiadałam Ryśkowi, jak się bałam Jego recenzji, to najpierw zdziwił się bardzo i stwierdził „Ale dlaczego? Taki jestem groźny?”, a następnie roześmiał serdecznie i powiedział, że powinnam wierzyć w siebie i być pewna tego co piszę, a nie dostawać zawału oczekując na czyjąś opinię. Coś w tym jest... Taki był Rysiek merytoryczny i serdeczny.

Mówił szczerze, bezpośrednio i bez subtelności o tym co robię i jak piszę. Tak jak i wspomniany na początku mojego tekstu prof. Wojciech Sokolewicz. A teraz już oby ich nie ma. Dlaczego?

\section{Wspomnienie Doktora Grzegorza Kucy}

Profesor Ryszard M. Małajny pozostanie dla mnie wzorem naukowca o olbrzymiej wiedzy, sumienności i pracowitości. Znający języki i komentujący z należytą refleksją, ale i uznaniem, poglądy wielu zagranicznych przedstawicieli nauki tworzył dzieła, które wielkimi literami wpisują się w dorobek nauki prawa. Piszący wyszukanym, a przy tym przystępnym językiem, potrafił w celny sposób zebrać w jednym miejscu poglądy wielu autorów, skonfrontować je i wyciągnąć precyzyjne wnioski. Jego prace czyta się na przysłowiowym wdechu. Był człowiekiem skromnym, może nieco zdystansowanym do środowiska naukowego, ale jednocześnie bardzo ciepłym i otwartym. Nie miał w zwyczaju wymądrzania się czy epatowania swoją wiedzą. W pamięci pozostanie mi Jego żołnierska postawa, szykowna garderoba, poczucie humoru oraz mocny, a przy tym życzliwy i zachęcający do rozmowy, uścisk dłoni. Na ten ostatni nie każdy mógł sobie zresztą zasłużyć. 
Spośród wszystkich naszych spotkań w szczególny sposób zapamiętałem pierwsze z nich przypadające na dzień 4 lipca 2007 r. W tym dniu przypadała nie tylko 231 rocznica ogłoszenia Deklaracji niepodległości Stanów Zjednoczonych (Profesor pozostaje wybitnym znawcą tej problematyki), ale także obrona mojej pracy doktorskiej (Profesor był jej Recenzentem). Pamiętam obawy, które towarzyszyły mi podczas naszego spotkania. Znając Jego dzieła i poglądy naukowe na temat podziału władzy czy władz (spór ten spędzał mi przez wiele lat sen z powiek) obawiałem się, że Profesor będzie chciał dokładnie sprawdzić stan mojej wiedzy. Do dziś dnia pamiętam znamienne dla mnie słowa, które podczas wygłaszania konkluzji recenzji wypowiedział Profesor: „skoro nawet Jezus Chrystus nie mógł każdemu dogodzić, to trudno, żeby uczynił to magistrant". Po ich wygłoszeniu w głowie wybrzmiała mi słynna paremia Sokratesa scio me nihil scire. Nic bardziej mylnego. Szybko okazało się, że Profesor zadał mi trzy istotne, aczkolwiek kontrowersyjne z punktu widzenia problematyki podziału władzy pytania, które pozwoliły mi na zaprezentowanie własnych poglądów. Po wielu latach sądzę, że na tym polega clou publicznej obrony pracy doktorskiej. Po jej zakończeniu Profesor podszedł do mnie, uśmiechnął się i uścisnął mi dłoń w ten charakterystyczny dla Niego sposób. Jeszcze tego samego dnia przeszliśmy „na Ty”, co potraktowałem jako niebywały zaszczyt i nobilitację.

Wraz z odejściem Profesora Małajnego kończy się pewna epoka. Epoka Profesorów-Wykładowców, których studenci wspominają nie tylko przy okazji sesji egzaminacyjnej czy rzadziej na wyższych latach studiów, ale także, o których krążą liczne anegdoty przekazywane następnym pokoleniom (nawet dzieciom czy wnukom). Zamknięto też ulubioną piekarnię Profesora na krakowskim Kazimierzu, gdzie wypiekano komiśniak, rodzaj ciemnego chleba z mieszaniny mąki żytniej, tradycyjnie wydawanego jako racje wojskowe, który zawsze zabierałem na nasze spotkania. Szkoda, że nie będzie ich więcej. 
Profesor Ryszard M. Małajny odszedł z Naszego grona. Jednak pozostał po Nim duży dorobek naukowy. To właśnie te dzieła stanowiące życiową spuściznę Profesora Małajnego, jak również wspomnienia, które zachowaliśmy powodują, że Profesor Ryszard M. Małajny na zawsze pozostanie w pamięci swych bliskich, przyjaciół, uczniów i współpracowników.

Professor, non omnes mortuus! 